\title{
Potentials of the use of brackish ground water in integrated aqua-agriculture systems
}

\section{Mohamed A.M.Moursy ${ }^{1}$, M. H. $\operatorname{Rady}^{1}$, Ahmed M. Ali ${ }^{1}$, Mohamed Elfetyany ${ }^{1}$ and W. Elbabl $^{2}$ \\ 1- Water Management Research Institute, National Water Research Center, Egypt}

2- Environmental and Climate Changes Research Institute, National Water Research Center, Cairo, Egypt

\begin{abstract}
Water scarcity is a great challenge and a growing problem for all countries. The present researchfocuses on the rational utilization of water resources with different quality through studying the effects of different parameters on water use efficiency and productivity, the investigation used different parameters such as water resources, sowing dates and water shortage on the amount of water applied, water use efficiency, yieldand net return of barley, in a semi-arid region during growing season 2014-2015. A Split plot layout with three replications was used. Two main plots represent water resources (fresh and brackish water). Sub plots were represented by the sowing dates of: $15^{\text {th }}$ Dec., $1^{\text {st }}$ Jan.and $15^{\text {th }}$ Jan.with water supply rates of: full irrigation, $80 \%$ and $60 \%$ of amount of water requirements.

The results indicated that, the highest value of irrigation water quantity using brackish water and fresh water were $2285 \mathrm{~m}^{3} / \mathrm{fed}$ and $2135 \mathrm{~m}^{3} /$ fed respectively at planting date of 15 December to add leaching needs and at $100 \%$ of irrigation water, while the lowest value for the quantity of irrigation water using brackish water and fresh water at $60 \%$ deficit was 1237 $\mathrm{m}^{3} /$ fed and $1156 \mathrm{~m}^{3} / \mathrm{fed}$ respectively at the planting date of January 15 in $60 \%$ deficit due to the low number of irrigation times. In the meantime, average water use efficiency was 1.28 , 1.46 and $1.53 \mathrm{~kg} / \mathrm{m}^{3}$ when using $100 \%, 80 \%$ and $60 \%$, respectively, with a yield reduction of $10 \%$ and $38 \%$ for the use of water $80 \%$ and $60 \%$ respectively compared to $100 \%$. The average efficiency of water uses when using brackish water was $1.48,1.65$ and $1.64 \mathrm{~kg} / \mathrm{m}^{3}$ when using $100 \%, 80 \%$ and $60 \%$ irrigation deficit respectively with a decrease in yield of $13 \%, 51 \%$ for the use of fresh water $80 \%$ and $60 \%$ respectively compared to $100 \%$.
\end{abstract}

Key words: Irrigation, freshwater, barley, fish farms, net return.

\section{INTRODUCTION}

Aquaculture is the farming of aquatic organisms, including fish, molluscs, crustaceans and aquatic plants.Farming implies some form ofintervention in the rearing process to enhance production, such as regular stocking, feeding, protection from wild species, etc. Farming also are implemented through individual or corporate investments of the stock being cultivated.

Barley is considered as the fourth most important crop after rice, wheat and maize in terms of cultivated area in the world. Below normal precipitation noticed in the recent years has resulted in countries like Egypt, Arab countriesto have a serious water shortage that could be defined as a crisis of irrigation water.

Aquaculture activities in Egypt are mostly located in the Northern part of the Nile Delta, clustered in the surrounding areas of the four northern Delta Lakes (Maruit, Edko, Boruls and Manzala). The command area occupied by this aquaculture is about (151,757 ha) producing annuallyfrom 2.8 to 8 tones/ha (Macfadyen et al., 2011).

Drainage water are reusedin the fish farming activity as a new source, rich with organic matter and it can also improve soil fertility and therefore the crops' productivity, this is expected to reduce the costs of added fertilizers and partially reduce the pollution in soil. The yield of potato crop and water use efficiency were 8 ton/fed $(1$ ha $=2.4$ fed $)$ and 2.9 
Mohamed A.M.Moursy et al.

$\mathrm{kg} / \mathrm{m}^{3}$ from fish farms using drainage water compared with 7.8 ton/fed and $2.9 \mathrm{~kg} / \mathrm{m}^{3}$ under traditional irrigation water (Abdelraouf \& Hoballah, 2014).

Also, the effect of irrigation shortage strategy needs to be investigated. Deficit irrigation is considered as an optimized strategy under which cultivated areas are made to suffer of irrigation water shortage and reduction in yield (English \& Raja, 1996; Ghaemi \& Tabarzad, 2014). The main idea of applying deficit irrigation practice is to know how far we can safe irrigation water and minimize irrigation times maintaining the least impact onthe crop yield.

Shabani et al. (2010) indicated that deficit irrigation hasdirect negative impact on the yield and yield quality of rapeseed such as weight of 1000-grain weight, seed oil and seed protein content.

Andrew (2008) determined planting date (mid-April (early), late May (mid), and midJune (delayed)) influenced crop and water use (WU) of barley. Early planting resulted in excellent forage yields. Water use was higher for the first planting date than for the second and third dates.

The main problem of the present research is to face the growing challenge of water resources scarcity and to investigate the potentials of using the brackish water as a water source for cultivation of strategic crops with an added economic value through the use of aqua fishponds.

The general objective is to develop and evaluate the use of a different quality of brackish water for integrated food systems in new lands, and to identify a number of crops that can be grown with brackish in the desert environment.The specific objectives are to study the effects of different parameters on water use efficiency and productivity, used different parameters such as water resources, sowing dates and water shortage on the amount of water applied, water use efficiency, yield and net return of barley crop, in a semi-arid region during growing season 2014-2015.

A Split plot layout with three replications was used to perform the experiment. Two main plots represent water resources (fresh and brackish water). Sub plots were represented by the sowing dates of: $15^{\text {th }}$ Dec., $1^{\text {st }}$ Jan. and $15^{\text {th }}$ Jan. with water supply rates of: full irrigation, $80 \%$ and $60 \%$ of amount of water requirements.

\section{MATERIALS AND METHODOLOGY}

Field experiments were carried out in open field conditions during the season of 20142015 at Wadi EL NatronResearch Station, Water Management and Irrigation Systems Research Institute, El-Behera Governorate to study the use of brackish ground water in integrated aqua-agriculture systems in new land in Egypt.

\section{Study area}

Wadi El-Natron research station is located at $30^{\circ} 23^{\prime} 19.89^{\prime \prime} \mathrm{N}$ latitude, $30^{\circ} 21^{\prime} 41.06^{\prime \prime}$ E longitude, while the altitude is $17.98 \mathrm{~m}$ above the sea level.

The experimental soil is classified as sandy soil. Undisturbed soil samples were collected from three different soil depths of $(0-20,20-40$ and $40-60 \mathrm{~cm})$ before cultivation to determine the physical and chemical characteristics of the experimental soil site. Some physical and chemical characteristics of the soil measured before the experiment under investigation are given in Tables $(1 \& 2)$. 
Potentials of the use of brackish ground water in integrated aqua-agriculture systems

Table (1): Some Physical Characteristics of the Experimental Soil.

\begin{tabular}{|c|c|c|c|c|c|c|c|c|}
\hline \multirow{2}{*}{$\begin{array}{c}\text { Soil layer } \\
(\mathrm{cm})\end{array}$} & \multicolumn{3}{|c|}{$\begin{array}{c}\text { Particle size } \\
\text { distribution } \%\end{array}$} & \multirow{3}{*}{$\begin{array}{c}\text { Textur } \\
\text { e class }\end{array}$} & \multicolumn{2}{|c|}{$\begin{array}{c}\text { Bd } \\
\left(\mathrm{gm} / \mathrm{cm}^{-3}\right)\end{array}$} & \multicolumn{3}{|c|}{$\begin{array}{c}\text { Moisture content by } \\
\text { weight }(\%)\end{array}$} \\
\cline { 2 - 6 } & Sand & Silt & Clay & & & F. C & W.P & A.W \\
\hline $0-20$ & 94.5 & 3.5 & 2.0 & & 1.65 & 8.03 & 3.33 & 4.7 \\
$20-40$ & 95.0 & 3.3 & 1.7 & Sandy & 1.56 & 9.13 & 3.14 & 5.99 \\
$40-60$ & 95.7 & 3.0 & 1.3 & & 1.44 & 10.07 & 2.99 & 7.08 \\
\hline
\end{tabular}

Table (2): Some Chemical Characteristics of the Experimental Soil.

\begin{tabular}{|c|c|c|c|c|c|c|c|c|c|c|c|}
\hline \multirow[t]{2}{*}{$\begin{array}{l}\text { Soil } \\
\text { layer }\end{array}$} & \multirow[t]{2}{*}{ SAR } & \multirow[t]{2}{*}{ PH } & \multirow{2}{*}{$\begin{array}{c}\text { EC } \\
(\mathrm{dS} / \mathrm{m}) \\
\text { at } 25^{\circ} \mathrm{c}\end{array}$} & \multicolumn{4}{|c|}{$\begin{array}{l}\text { Soluble anions } \\
(\text { meq /l) }\end{array}$} & \multicolumn{4}{|c|}{$\begin{array}{l}\text { Soluble cations } \\
(\text { meq /l) }\end{array}$} \\
\hline & & & & $\mathrm{CO}_{3}{ }^{--}$ & $\mathrm{HCO}_{3}$ & $\mathrm{Cl}^{-}$ & $\mathrm{SO}_{4}^{--}$ & $\mathrm{Ca}^{++}$ & $\mathrm{Mg}^{++}$ & $\mathrm{Na}^{+}$ & $\mathrm{K}^{+}$ \\
\hline $0-20$ & 1.66 & 8.23 & 1.46 & 0.1 & 0.93 & 1.98 & 9.61 & 6.23 & 2.24 & 3.44 & 0.51 \\
\hline $20-40$ & 1.74 & 8.11 & 1.56 & 0.1 & 1.15 & 2.05 & 9.85 & 6.45 & 2.26 & 3.76 & 0.58 \\
\hline $40-60$ & 1.84 & 7.97 & 1.63 & 0.1 & 1.33 & 2.11 & 10.16 & 6.65 & 2.29 & 3.91 & 0.65 \\
\hline
\end{tabular}

\section{Materials}

- Irrigation system and equipment's:Sprinkler irrigation system was used in the experimental. It contains the following general components:

- Pump: For the ground water well (first source of water). An electrical centrifugal pump was used with 60 hpengine power and a discharge of $100 \mathrm{~m}^{3} / \mathrm{h}$ at 4 bar operating pressure head.

And for the second source of brackish water (reservoir). An electrical surface pump was used with $40 \mathrm{hp}$ engine power and a discharge of $90 \mathrm{~m}^{3} / \mathrm{h}$ at 4 bar operating pressure head.

- Control unit: The control unit follows the pump however; its objective is to control the pressures and water quantities. It also used to filter water and can be used to add fertilizers.The control unit consists of: non-return valve, valve, pressure gauge, fertilizer venture, sand filters, water flow meter and air release valveFigure (1).

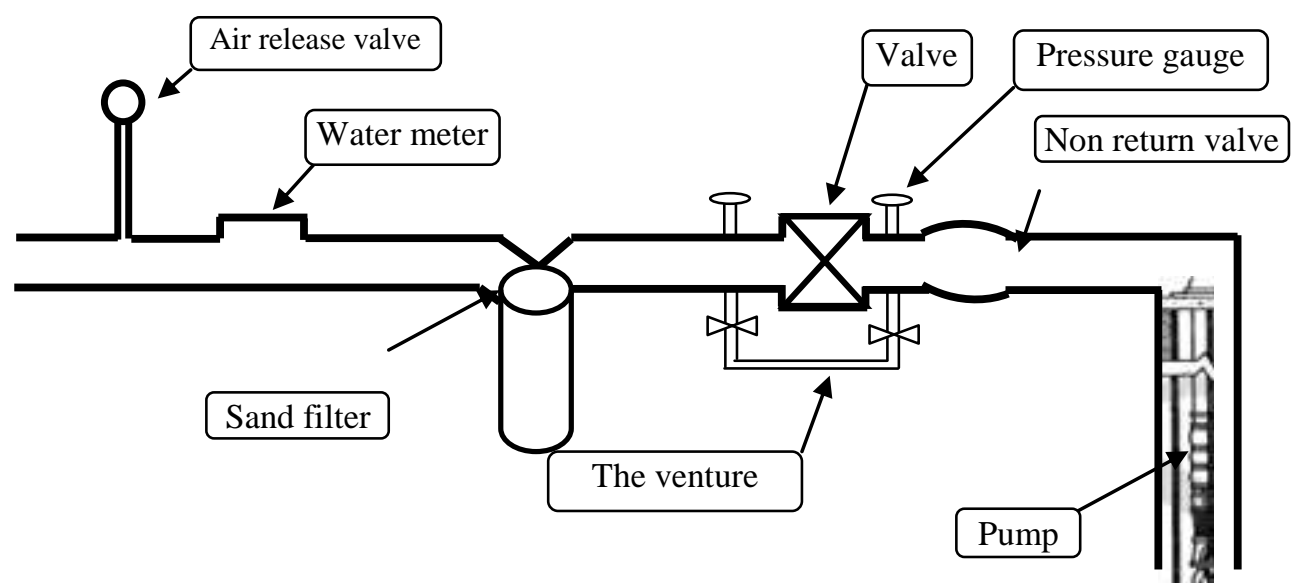

Fig. (1): The diagram of control unit.

- Pipe network:Pipe network consists of a main line, sub mains and secondary pipes.

- Sprinkler irrigation system contents the general components in addition to the following:Riser, manifold pipes, lateral lines, sprinkler riser and rotating sprinklers 0.75 inch out diameter, $1 \mathrm{~m}^{3} / \mathrm{h}$ discharge under 2.2 bars operating pressure. 
Mohamed A.M.Moursy et al.

- Soil preparation and planting dates for barley: During soil preparation the land was plowed using chisel plow. Organic manure was added, in addition, chemical fertilizers were added and mixed in the soil by rates as follow through all experimental locations:

a) Super phosphate $\left(15.5 \% \mathrm{P}_{2} \mathrm{O}_{5}\right)$ was added at a rate of $100 \mathrm{~kg} /$ fed before plowing.

b) Nitrate $(33.5 \% \mathrm{~N})$ was added at a rate of $200 \mathrm{~kg} / \mathrm{fed}$ divided on 5 times the first one after thinning and the other 4 times were applied at 15 days intends.

c) Potassium sulphate $\left(48 \% \mathrm{~K}_{2} \mathrm{O}\right)$ was added at a rate of $50 \mathrm{~kg} / \mathrm{fed}$ on 2 times with nitrate.

- Planting dates: Barelywas planted manually at three dates of 15/12/2014, 1/1/2015 and $15 / 1 / 2015$.

- Irrigation water: The two quality of water was used (well water and brackish water "reservoir") under this study. The results of some chemical characteristics of the water under investigation are given in Tables $(3 \& 4)$.

Table (3): Physical and Chemical Characteristics of Irrigation Water by Well

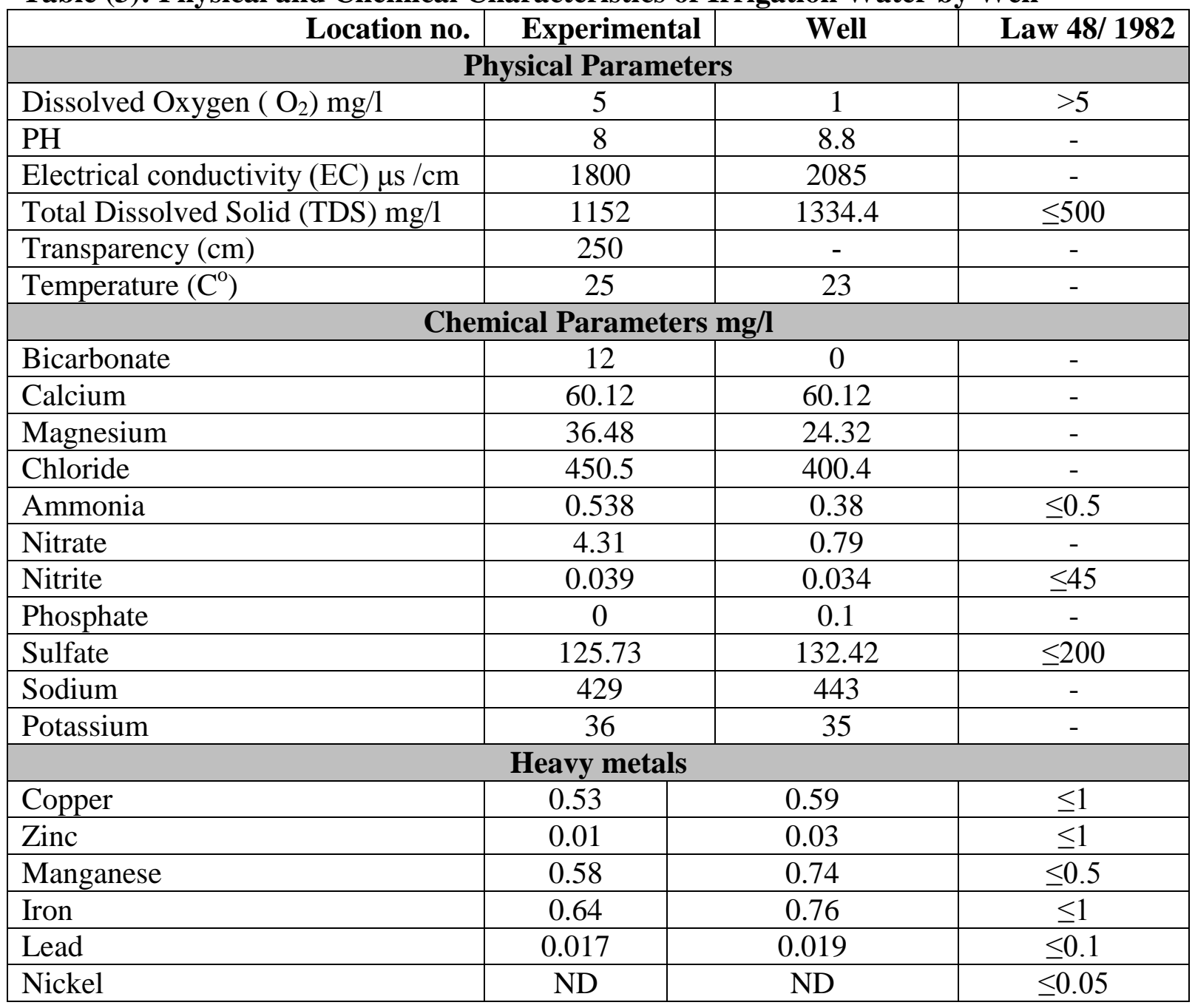


Potentials of the use of brackish ground water in integrated aqua-agriculture systems

Table (4): Physical and Chemical Characteristics of Irrigation Water by Reservoir

\begin{tabular}{|c|c|c|c|}
\hline Location no. & $\begin{array}{c}\text { Experiment } \\
\text { al } \\
\end{array}$ & Reservoir & $\begin{array}{l}\text { Fish Farming } \\
\text { Water Quality }\end{array}$ \\
\hline \multicolumn{4}{|c|}{ Physical Parameters } \\
\hline Dissolved Oxygen $\left(\mathrm{O}_{2}\right) \mathrm{mg} / \mathrm{l}$ & 5 & 1.2 & $\geq 5$ \\
\hline $\mathrm{PH}$ & 8.7 & 9 & $7-9.5$ \\
\hline Electrical conductivity (EC) us/ cm & 1700 & 2080 & - \\
\hline Total Dissolved Solid (TDS) mg/l & 1088 & 1331.2 & $<3000$ \\
\hline Temperature $\left(\mathrm{C}^{\mathrm{o}}\right)$ & 19 & 22 & $15-35$ \\
\hline \multicolumn{4}{|c|}{ Chemical Parameters mg/l } \\
\hline Ammonia & 0.365 & 0.444 & $<1$ \\
\hline Nitrate & 0.02 & 0.01 & $0-100$ \\
\hline Phosphate & 3.98 & 1.39 & $0.03-2$ \\
\hline Sulfate & 154.03 & 127.94 & $\leq 200$ \\
\hline Sodium & 424 & 414 & - \\
\hline Potassium & 36 & 35 & - \\
\hline
\end{tabular}

\section{Agro-meteorological data:}

The maximum and minimum temperatures, relative humidity, wind speed and sunshine (h) were measured during the running of the experiment (Table 5).

Table (5): Average Agro-meteorological data in month at Wadi EL Natrown.

\begin{tabular}{|c|c|c|c|c|c|c|c|c|c|c|}
\hline Month & $\begin{array}{c}\text { Temp } \\
\text { Out }\end{array}$ & $\begin{array}{c}\text { Hi } \\
\text { Temp }\end{array}$ & $\begin{array}{c}\text { Low } \\
\text { Temp }\end{array}$ & $\begin{array}{c}\text { Out } \\
\text { Hum }\end{array}$ & $\begin{array}{c}\text { Dew } \\
\text { Pt. }\end{array}$ & $\begin{array}{c}\text { Wind } \\
\text { Speed }\end{array}$ & $\begin{array}{c}\text { Heat } \\
\text { Index }\end{array}$ & $\begin{array}{c}\text { THW } \\
\text { Index }\end{array}$ & $\begin{array}{c}\text { Rain } \\
\text { Rate }\end{array}$ & $\begin{array}{c}\text { Solar } \\
\text { Rad. }\end{array}$ \\
\hline November & 17.17 & 17.47 & 16.89 & 75.56 & 12.32 & 4.58 & 17.13 & 17.06 & 0.02 & 113.03 \\
\hline December & 14.84 & 15.14 & 14.56 & 61.78 & 6.82 & 6.56 & 14.25 & 13.88 & 0.00 & 122.88 \\
\hline January & 13.43 & 13.72 & 13.16 & 59.15 & 4.58 & 7.43 & 12.71 & 12.20 & 0.01 & 135.10 \\
\hline February & 14.55 & 14.85 & 14.25 & 61.84 & 6.21 & 7.60 & 13.90 & 13.40 & 0.00 & 164.39 \\
\hline March & 17.77 & 18.10 & 17.45 & 65.00 & 10.13 & 8.08 & 17.41 & 17.15 & 0.00 & 212.00 \\
\hline April & 19.77 & 20.16 & 19.40 & 58.66 & 9.77 & 8.26 & 19.27 & 19.01 & 0.04 & 276.31 \\
\hline May & 23.67 & 24.03 & 23.34 & 59.93 & 14.45 & 7.80 & 23.75 & 23.66 & 0.00 & 274.42 \\
\hline
\end{tabular}

\section{METHODS}

The methodology of carrying out the experiments were as follows:The total experimental area of the experiment was reached $10368 \mathrm{~m}^{2}$ divided into three main plots: $3456 \mathrm{~m}^{2}$ for first planting date, $3456 \mathrm{~m}^{2}$ for second planting date and $3456 \mathrm{~m}^{2}$ for third planting date.

The treatments of experiment were based on the following parameters:

- Water quality: Two irrigation water quality were used for irrigating barely

○ Well (fresh water).

o Fish farms (brackish water)

- Water regime

- $100 \%$ of amount of water applied.

- $80 \%$ of amount of water applied.

- $60 \%$ of amount of water applied. 


\section{Mohamed A.M.Moursy et al.}

- Planting dates:Barely was cultivated at three dates as follows:

o 15th Dec.

o 1 st Jan.

○ 15th Jan.

The layout of sprinkler irrigation systems were illustrated in Figure (2).

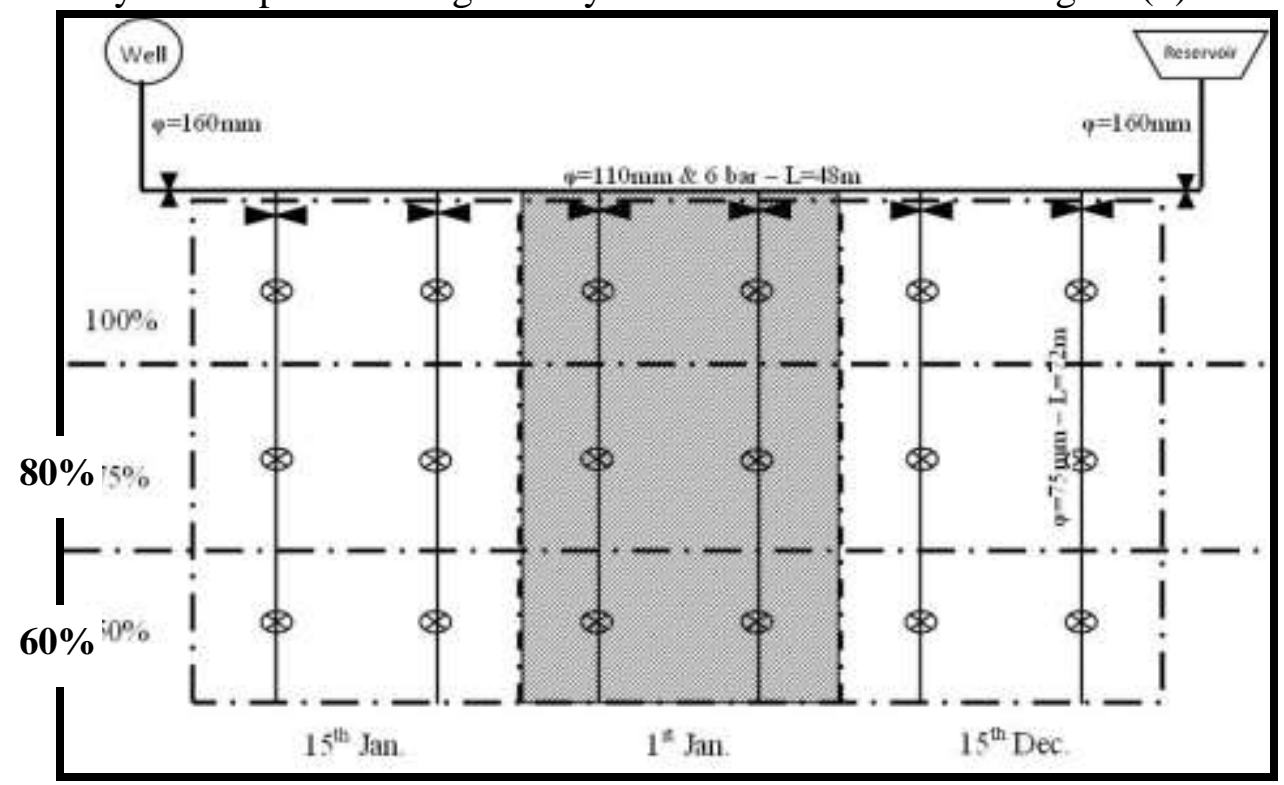

Fig. (2): Layout of sprinkler irrigation system experiments.

\section{Measurement and determinations}

\section{- Irrigation characteristics}

Amount of water applied: The irrigation requirements were calculated according to the equation given by Israelsen and Hansen (1962) as follows:

$$
\mathrm{D}_{\text {aiw }}=\frac{\text { F.C. }-\theta_{1}}{100} \mathrm{XB}_{\mathrm{d}} \mathrm{X} \mathrm{d}
$$

Where:

$\mathrm{D}_{\text {aiw }}$ : Depth of irrigation water applied (mm)

F. C.: Soil moisture content at field capacity (\%)

$\Theta_{1} \quad$ : Soil moisture content before irrigation (\%)

$\mathrm{B}_{\mathrm{d}} \quad$ : Bulk density $\left(\mathrm{g} / \mathrm{cm}^{3}\right)$

d : Soil depth (mm)

Yield components at harvest: samples of plants were taken from each treatment to estimate the following:

○ Seed yield (kg/fed.).

○ Straw yield (kg/fed.).

- Harvest Index (\%)

The physiological efficiency of a crop to convert dry matter into economic yield is determined by the harvest index (HI).

$$
H I=\frac{\text { grain dry mass }}{\text { total above ground plant dry mass }} \times 100, \%
$$

Water use efficiency (WUE): It was determined according to (Pene \& Edi, 1996) using the following equation: 
Potentials of the use of brackish ground water in integrated aqua-agriculture systems

$$
\text { WUE }=\frac{\text { Yield }(\mathrm{kg} / \mathrm{fed} .)}{\text { Amount of water applied }\left(\mathrm{m}^{3} / \mathrm{fed}\right)}, \mathrm{kg} / \mathrm{m}^{3}
$$

\section{Economic analysis}

- Total return (LE/fed.) was calculated with the following equation:

Total return $=$ yield of barley $($ price $(\mathrm{LE} / \mathrm{kg}) \times$ productivity $(\mathrm{kg} / \mathrm{fed}))+$ yield of fish $($ price

$$
(\mathrm{LE} / \mathrm{kg}) \times \text { productivity }(\mathrm{kg} / \mathrm{fed}))
$$

- Total costs (LE/fed.) was calculated with the following equation for barley and fish:

Total cost $=$ fixed cost + variable cost

- Net return (LE/fed.) was calculated with the following equation:

Net return $=$ Total return - Total costs

- Water productivity $\left(\mathrm{LE} / \mathrm{m}^{3}\right)$ was calculated by using the following formula:

$$
\text { Water productvity }=\frac{\text { Net return (LE/fed.) }}{\text { Amount of water applied }\left(\mathrm{m}^{\mathrm{a}} / \mathrm{fed}\right)}=\mathrm{LE} / \mathrm{m}^{\mathrm{a}}
$$

\section{Effect of Reuse ofbrackish water on Soil}

\section{RESULTS AND DISCUSSION}

Table (6) shows that, the soil salinity was reduced to $1.33 \mathrm{dS} / \mathrm{m}$ after harvesting compared to salinity level of $1.55 \mathrm{dS} / \mathrm{m}$ before planting when fish bond drainage was used, while the salinity of soil after planting using fresh water was about $1.23 \mathrm{dS} / \mathrm{m}$.Also, Nitrogen increased in soil from $177 \mathrm{~kg} / \mathrm{fed}$ before planting to $253 \mathrm{~kg} / \mathrm{fed}$ after planting when usingbrackish water while nitrogen increased to $180 \mathrm{~kg} / \mathrm{fed}$ after agriculture when using fresh water. The amount of potassium in the form of potassium oxide increased from $1321 \mathrm{~kg} / \mathrm{fed}$ before planting to $2254 \mathrm{~kg} / \mathrm{fed}$ after planting whenbrackish water was used, while the use of

\begin{tabular}{|c|c|c|c|c|c|c|c|c|}
\hline \multirow{2}{*}{ Soil } & \multirow{2}{*}{$\begin{array}{r}\text { Water } \\
\text { Source }\end{array}$} & \multirow{2}{*}{ SAR } & \multirow{2}{*}{ PH } & \multirow{2}{*}{$\begin{array}{c}\text { EC } \\
(\mathrm{dS} / \mathbf{m})\end{array}$} & \multirow{2}{*}{$\begin{array}{c}\mathrm{N} \\
(\mathrm{kg} / \mathrm{fed})\end{array}$} & \multirow{2}{*}{$\begin{array}{c}\mathrm{P}_{\mathbf{2}} \mathrm{O}_{\mathbf{5}} \\
\text { (kg/fed) }\end{array}$} & \multirow{2}{*}{$\begin{array}{c}\mathrm{K}_{2} \mathrm{O} \\
(\mathrm{kg} / \mathrm{fed})\end{array}$} & \multirow{2}{*}{$\begin{array}{c}\mathrm{S} \\
\text { (kg/fed) }\end{array}$} \\
\hline & & & & & & & & \\
\hline Before & & 1.75 & 8.10 & 1.55 & 177 & 10.13 & 1321 & 18.1 \\
\hline \multirow[b]{2}{*}{ After } & Fresh Water & 1.84 & 8.2 & 1.23 & 180 & 10 & 1350 & 13 \\
\hline & $\begin{array}{l}\text { Fish bond } \\
\text { drainage } \\
\text { water }\end{array}$ & 1.91 & 8.37 & 1.33 & 253 & 11.34 & 2254 & 12.4 \\
\hline
\end{tabular}
fresh water resulted in potassium oxide to slightly increase to $1350 \mathrm{~kg} / \mathrm{fed}$.

Table(6): Chemical analysis of soil and water using fresh andbrackish water

\section{Amount of irrigation water applied}

Figure (3) shows that, the highest values for the quantity of irrigation water used were when usingbrackish water because of adding leaching needs to prevent accumulation of salts.The highest values for irrigation water were achieved when using the water of fish bond drainage where it reached $2285 \mathrm{~m}^{3} /$ fed.and $2171 \mathrm{~m}^{3} /$ fed.and $2026 \mathrm{~m}^{3} / \mathrm{fed}$. in the planting dates of 15 December and 1 January and 15 January respectively, $100 \%$ of the quantity of irrigation water. Also, irrigation water quantities using fresh water at $100 \%$ was about 2135 $\mathrm{m}^{3} /$ fed.and $2028 \mathrm{~m}^{3} /$ fed.and $1927 \mathrm{~m}^{3} /$ fed. at the planting dates of December 15, January 1 and January 15, respectively. While the lowest value for the irrigation water using fresh water was $60 \%$ of the irrigation water was about $1156 \mathrm{~m}^{3} /$ fed.at the planting date of January 15 , while the lowest value of irrigation water usingbrackish water was about $1237 \mathrm{~m}^{3} / \mathrm{fed}$. with $60 \%$ of irrigation water at planting date of January 15 due to the low number of irrigations. 
Mohamed A.M.Moursy et al.

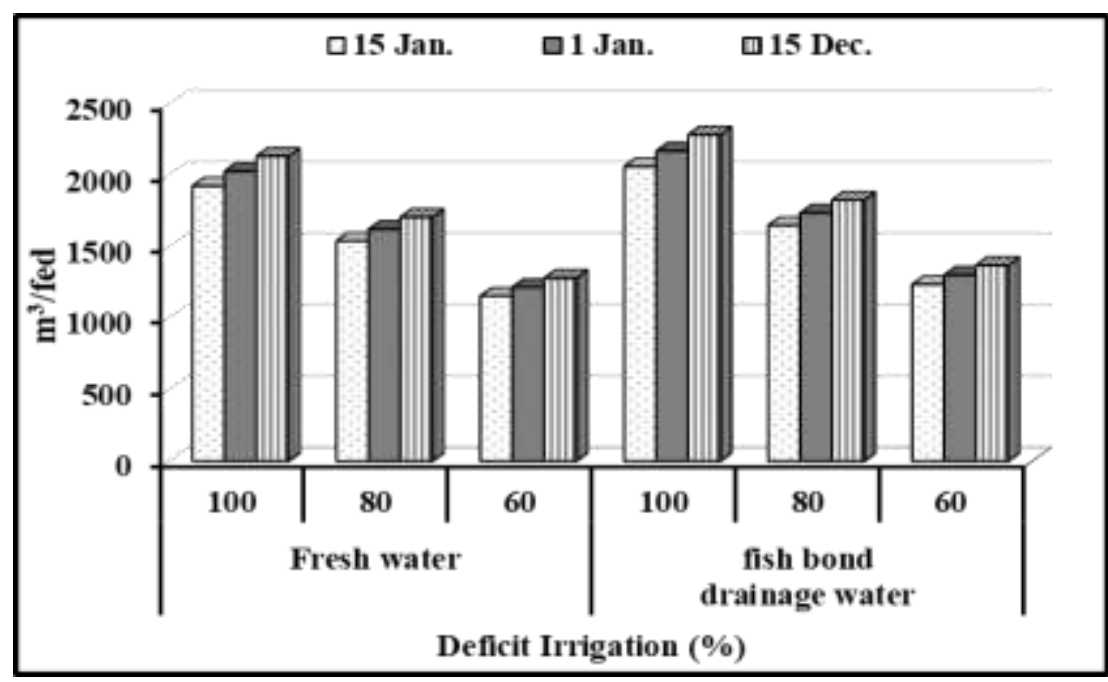

Fig. (3):Amount of irrigation water with deficit irrigation using fresh andbrackish water for different planting dates

\section{Yield components at harvest}

Seed yield

With regard the effect of water quality on seed yield, data show that the highest value of seed yield was found under brackish under all treatments. Brackish water increased the seed yield from 127.1 to $175.4 \mathrm{~kg} / \mathrm{fed}$. compared with fresh water at planting date $1 \mathrm{Jan}$. under $100 \%$ water regime. Using fresh water reduced the seed yield by $21.3 \%$ compared with fresh water under $60 \%$ water regimes, $15^{\text {th }}$ Dec. and planting date. The obtained data indicated that the brackish water was significant on seed yield under all treatment compared with fresh water at planting date 1 Jan. under $100 \%$ water regime (Fig. 4).

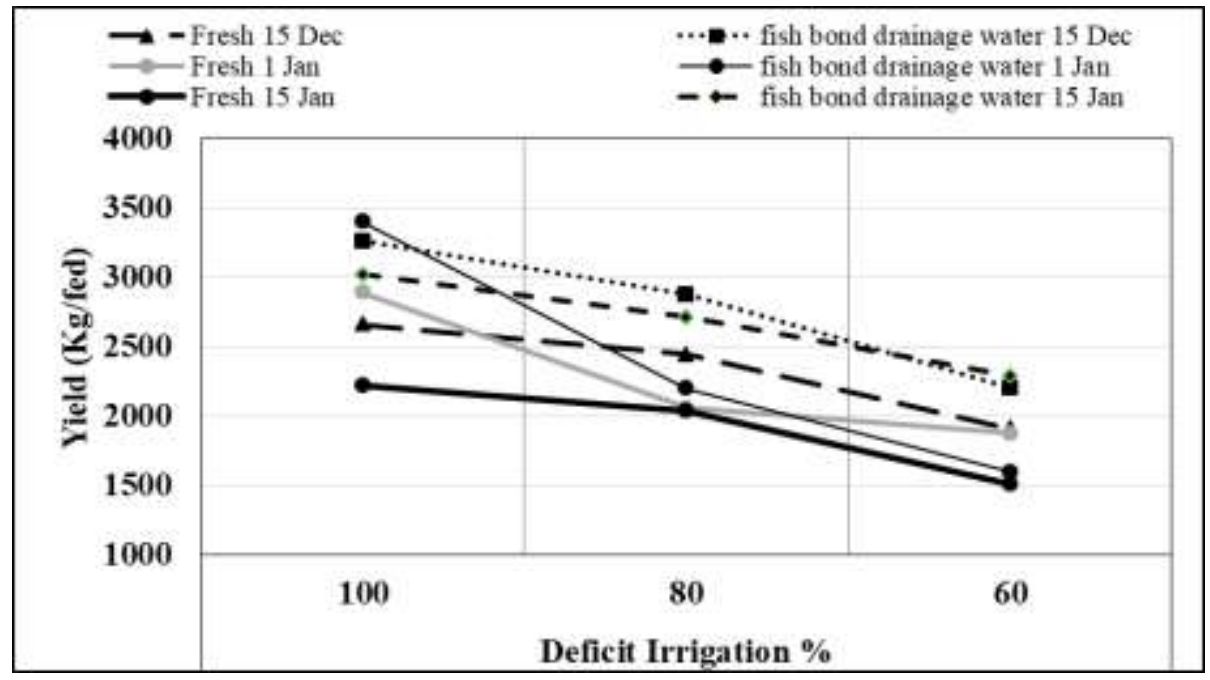

Fig. (4): Yield seed with deficit irrigation using fresh and brackish water for different

\section{Straw yield}

planting dates

As to using water quality, the obtained results from Figure (5) show that under all treatments the highest value at $100 \%$ water regime by using brackish water compared to fresh water and the lowest Value at $60 \%$ water regime by using brackish water compared to fresh water. Also, the highest values of the straw yield were $5080 \mathrm{~kg} / \mathrm{fed}$ under $100 \%$ water regime, 1 Jan. planting date by using brackish water, while the lowest values was $3024 \mathrm{~kg} / \mathrm{fed}$ 
under $60 \%$ water regime, with planting date $15^{\text {th }}$ Dec. brackish water. The results showed that it was significantly on values of the straw yield increased under $100 \%$ water regime, 1 Jun. planting date by using brackish water

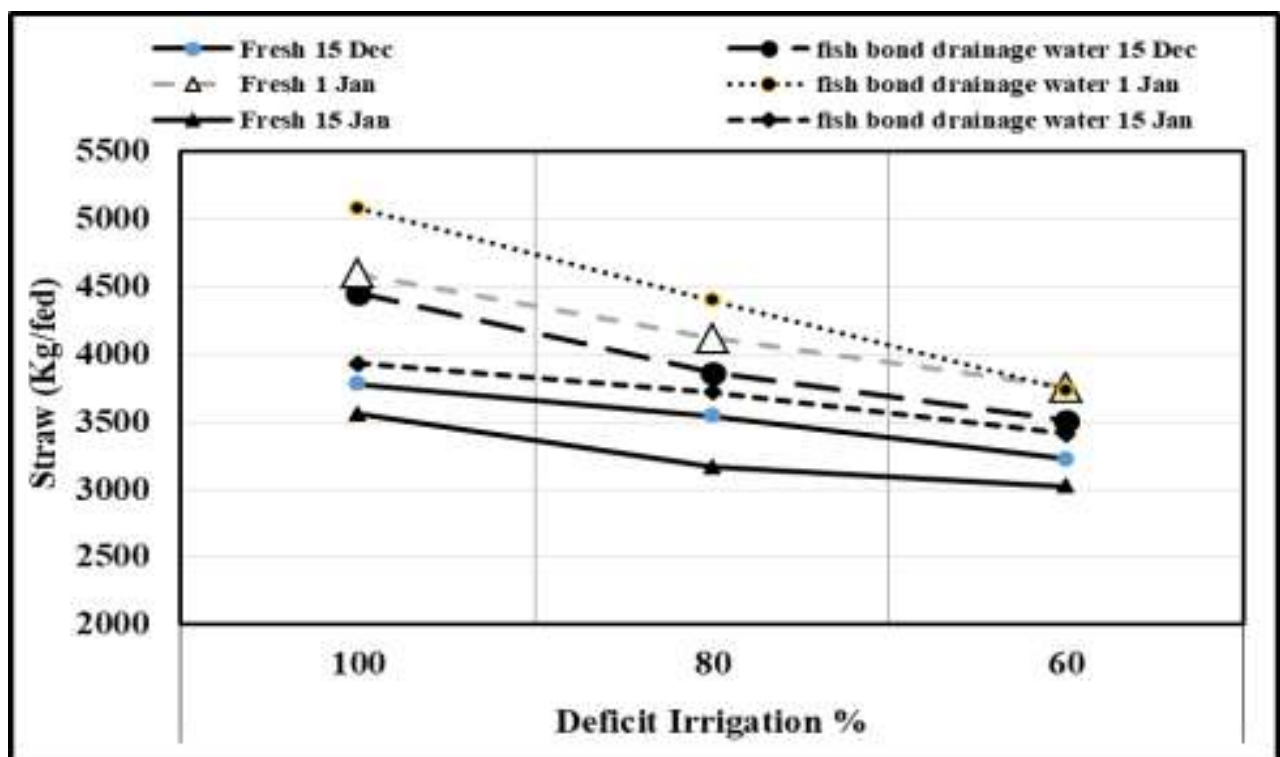

Fig. (5): Straw seed with deficit irrigation using fresh andbrackish water for different planting dates

\section{Harvest Index}

Figure (6) shows the comparison of harvest index between fresh water and brackish water with water deficit and different planting dates. The results indicated that the highest values for harvest index were when using fish water compared to fresh water. For water deficit, the highest values were when using a water deficit of $1000 \%$ and the lowest value was when using $60 \%$ of the irrigation water both in fish drainage and freshwater. For planting dates, the highest harvest index values were January 15 and the lowest value was on January 1, in fresh water. Also, the obtained data indicated that the harvest index was significant with fish water compared to fresh water.

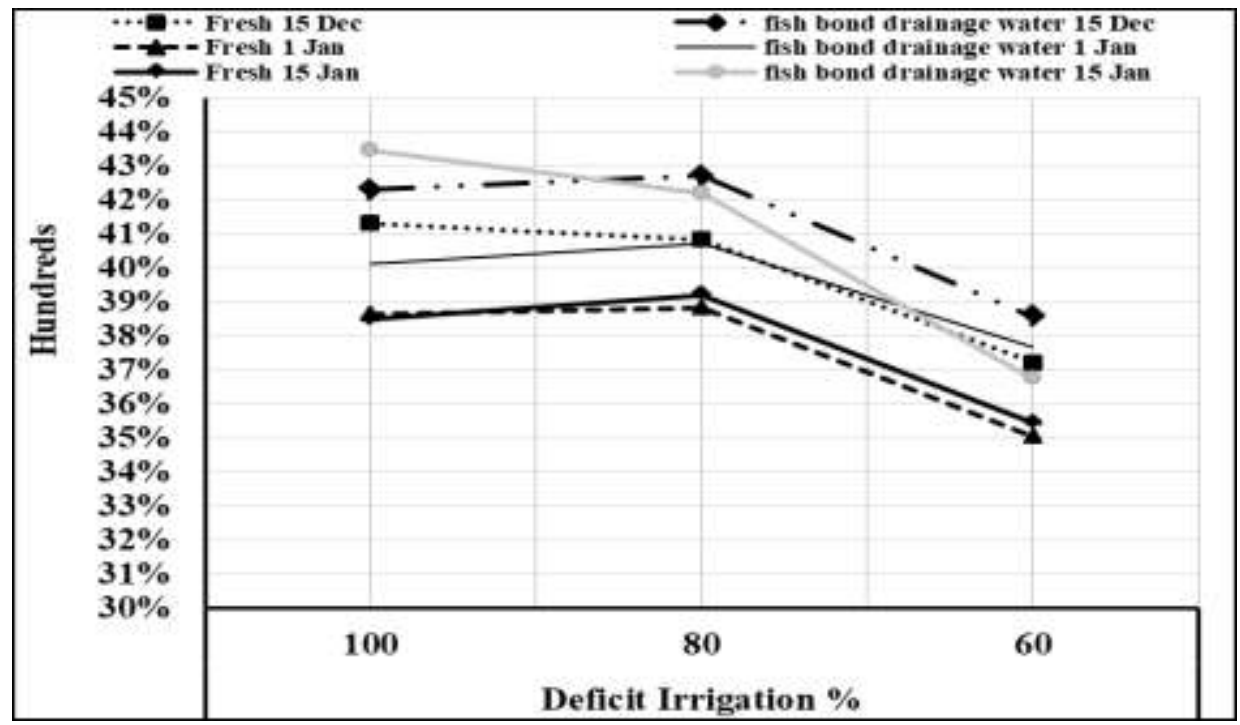

Fig. (6): Harvest Index with deficit irrigation using fresh and brackish water for different planting dates 
Mohamed A.M.Moursy et al.

\section{Water Use Efficiency}

Table (7) shows that the average water use efficiency when using fresh were 1.28, 1.46 and $1.53 \mathrm{~kg} / \mathrm{m}^{3}$ when using water deficit $100 \%, 80 \%$ and $60 \%$ respectively. The average efficiency of water use when using brackish water was $1.48,1.65$ and $1.64 \mathrm{~kg} / \mathrm{m}^{3}$ when using water deficit $100 \%, 80 \%$ and $60 \%$, respectively. Also, mean average water use efficiency when using fresh water were $1.4,1.6$ and $1.3 \mathrm{~kg} / \mathrm{m}^{3}$ in planting dates 15 December, 1 January and 15 January, respectively. The average efficiency of water use when using brackish water was $1.5,1.7$ and $1.6 \mathrm{~kg} / \mathrm{m}^{3}$ when using no water deficit in planting dates 15 December, 1 January and 15 January, respectively.

Table (7): Water use efficiency with deficit irrigation using fresh andbrackish water

\begin{tabular}{|c|c|c|c|c|c|c|c|c|c|c|c|c|}
\hline & \multicolumn{6}{|c|}{ Fresh Water } & \multicolumn{6}{|c|}{ Brackish Water } \\
\hline & \multicolumn{3}{|c|}{ Deficit Irrigation } & \multicolumn{3}{|c|}{ Planting Date } & \multicolumn{3}{|c|}{ Deficit Irrigation } & \multicolumn{3}{|c|}{ Planting Date } \\
\hline & $\begin{array}{c}100 \\
\%\end{array}$ & $\begin{array}{l}80 \\
\%\end{array}$ & $\begin{array}{l}60 \\
\%\end{array}$ & $\begin{array}{c}15 \\
\text { Dec } \\
\text {. }\end{array}$ & $\begin{array}{c}1 \\
\text { Jan }\end{array}$ & $\begin{array}{c}15 \\
\text { Jan } \\
\text {. }\end{array}$ & $\begin{array}{c}100 \\
\%\end{array}$ & $\begin{array}{l}80 \\
\%\end{array}$ & $\begin{array}{l}60 \\
\%\end{array}$ & $\begin{array}{c}15 \\
\text { Dec. }\end{array}$ & $\begin{array}{c}1 \\
\text { Jan }\end{array}$ & $\begin{array}{c}15 \\
\text { Jan } \\
\text {. }\end{array}$ \\
\hline $\begin{array}{c}\text { WUE } \\
\left(\mathrm{Kg} / \mathrm{m}^{3}\right)\end{array}$ & 1.28 & 1.46 & 1.53 & 1.4 & 1.6 & 1.3 & 1.487 & 1.653 & 1.647 & 1.5 & 1.7 & 1.6 \\
\hline
\end{tabular}

Figure (7) shows the comparison of water use efficiency between fresh water and brackish water with water deficit and different planting dates. The results indicated that the highest values for water use efficiency were when using fish water compared to fresh water. For water deficit, the highest values were when using a water deficit of $80 \%$ and the lowest value was when using $100 \%$ of the irrigation water both in fish drainage and freshwater. For planting dates, the highest water use efficiency values were January 1 and January 15 and the lowest value was on December 15, both in fish drainage and fresh water. The highest values of water use efficiency were $1.74 \mathrm{~kg} / \mathrm{m}^{3}$ at $80 \%$ water deficit at 1 January planting time usingbrackish water and $1.73 \mathrm{~kg} / \mathrm{m}^{3}$ at $60 \%$ water deficit at 1 January planting time usingbrackish water and the lowest value was $1.15 \mathrm{~kg} / \mathrm{m}^{3}$ at $100 \%$ irrigation on December 15 using fresh water.

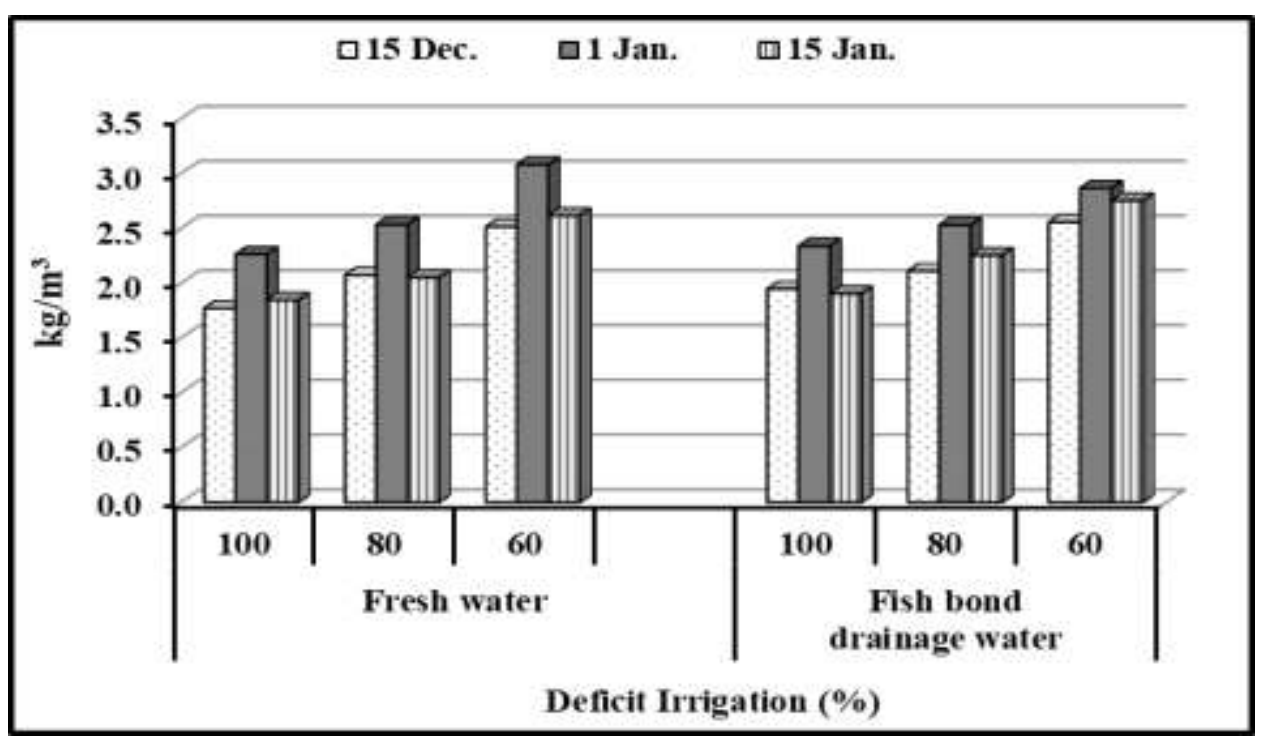

Fig. (7): Water use efficiency with deficit irrigation using fresh and brackish water. 
Potentials of the use of brackish ground water in integrated aqua-agriculture systems

\section{Net return}

From Figure (8), results could be summarized as follows:

- The highest net return occurred when brackish water was used compared with fresh water at the date of planting of January 1 using $100 \%$ of irrigation water.

- The lowest net yield was at the planting date of January 15 with $60 \%$ of the water deficit using freshwater and brackish water.

- The highest net return is about LE 16020/fed. followed by 14249 LE/fed. and 13457 LE/fed.using the water of fish bond drainage at $100 \%$ of the irrigation water at planting date of 1 January, 15 December and 15 January respectively, and the net return of about $6501 \mathrm{LE} /$ fed.using fresh water at $60 \%$ of irrigated water in January 15.

- The average net return using brackish water was about $11950 \mathrm{LE} / \mathrm{fed}$. while the net return when using fresh water was about $9150 \mathrm{LE} / \mathrm{fed}$.

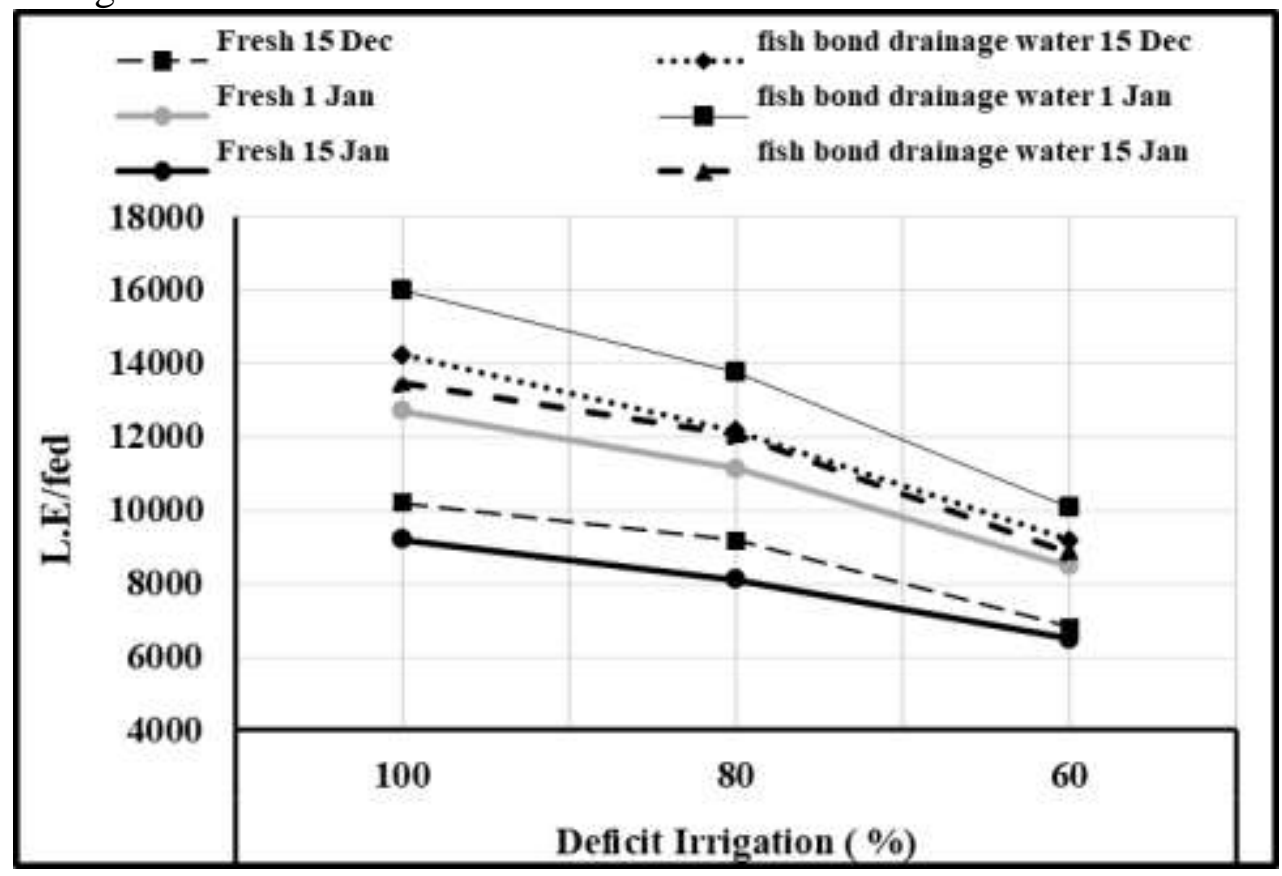

Fig. (8): Net return with deficit irrigation using fresh, and brackish water for different

Water Productivity planting dates

Table (8) shows that the average water productivity when using fresh water was 5.27, 5.84 and $5.97 \mathrm{LE} / \mathrm{m}^{3}$ when using water deficit $100 \%, 80 \%$ and $60 \%$ respectively, and the average water productivity when using the drainage water of fish bond was 6.71, 7.30 and $7.20 \mathrm{LE} / \mathrm{m}^{3}$ using water deficit of $100 \%, 80 \%$ and $60 \%$, respectively.Also, the average water productivity when using fresh water was $5.16,6.70$ and $5.22 \mathrm{LE} / \mathrm{m}^{3}$ in the planting dates of December 15, January 1 and January 15 respectively, and the average water productivity when using the drainage water of fish bonds was $6.53,5.16$ and $6.99 \mathrm{LE} / \mathrm{m}^{3}$ when using $100 \%$ water in agriculture dates 15 December, 1 January and 15 January, respectively.

Table (8): Water productivity with deficit irrigation using fresh, andbrackish water

\begin{tabular}{|c|c|c|c|c|c|c|c|c|c|c|c|c|}
\hline & \multicolumn{4}{|c|}{ Fresh Water } & \multicolumn{4}{c|}{ Fish Bond Drainage Water } \\
\cline { 2 - 12 } & \multicolumn{4}{|c|}{ Deficit Irrigation } & \multicolumn{2}{|c|}{ Planting Date } & \multicolumn{2}{c|}{ Deficit Irrigation } & \multicolumn{3}{c|}{ Planting Date } \\
\cline { 2 - 12 } & $\begin{array}{c}\mathbf{1 0 0} \\
\mathbf{\%}\end{array}$ & $\begin{array}{c}\mathbf{8 0} \\
\mathbf{\%}\end{array}$ & $\begin{array}{c}\mathbf{6 0} \\
\mathbf{\%}\end{array}$ & $\begin{array}{c}\mathbf{1 5} \\
\text { Dec. }\end{array}$ & $\begin{array}{c}\mathbf{1} \\
\text { Jan. }\end{array}$ & $\begin{array}{c}\mathbf{1 5} \\
\text { Jan. }\end{array}$ & $\begin{array}{c}\mathbf{1 0 0} \\
\mathbf{\%}\end{array}$ & $\begin{array}{c}\mathbf{8 0} \\
\mathbf{\%}\end{array}$ & $\begin{array}{c}\mathbf{6 0} \\
\mathbf{\%}\end{array}$ & $\begin{array}{c}\mathbf{1 5} \\
\text { Dec. }\end{array}$ & $\begin{array}{c}\mathbf{1} \\
\text { Jan. }\end{array}$ & $\begin{array}{c}\mathbf{1 5} \\
\text { Jan. }\end{array}$ \\
\hline $\begin{array}{c}\text { W.P } \\
\left(\mathrm{L} . \mathrm{E} / \mathrm{m}^{3}\right)\end{array}$ & 5.27 & 5.84 & 5.97 & 5.16 & 6.70 & 5.22 & 6.71 & 7.30 & 7.20 & 6.53 & 5.16 & 6.99 \\
\hline
\end{tabular}


Mohamed A.M.Moursy et al.

Figure (9) shows the results of water productivity using freshwater compared to brackish water with water deficit and different planting dates. The results can be summarized as follows:

- The highest values for water productivity were when fish water was used compared to fresh water.

- For water deficit, the highest values were when using water deficit $80 \%$ and the lowest value was when using $100 \%$ of the irrigation water in fresh water.

- The highest values for water productivity were $7.94 \mathrm{LE} / \mathrm{m}^{3}$ and $7.75 \mathrm{LE} / \mathrm{m}^{3}$ usingbrackish water at the planting date of January 1 at $80 \%$ and $60 \%$ water deficit respectively and the lowest value was $4.79 \mathrm{LE} / \mathrm{m}^{3}$ using $100 \%$ fresh water at irrigation time 15 December.

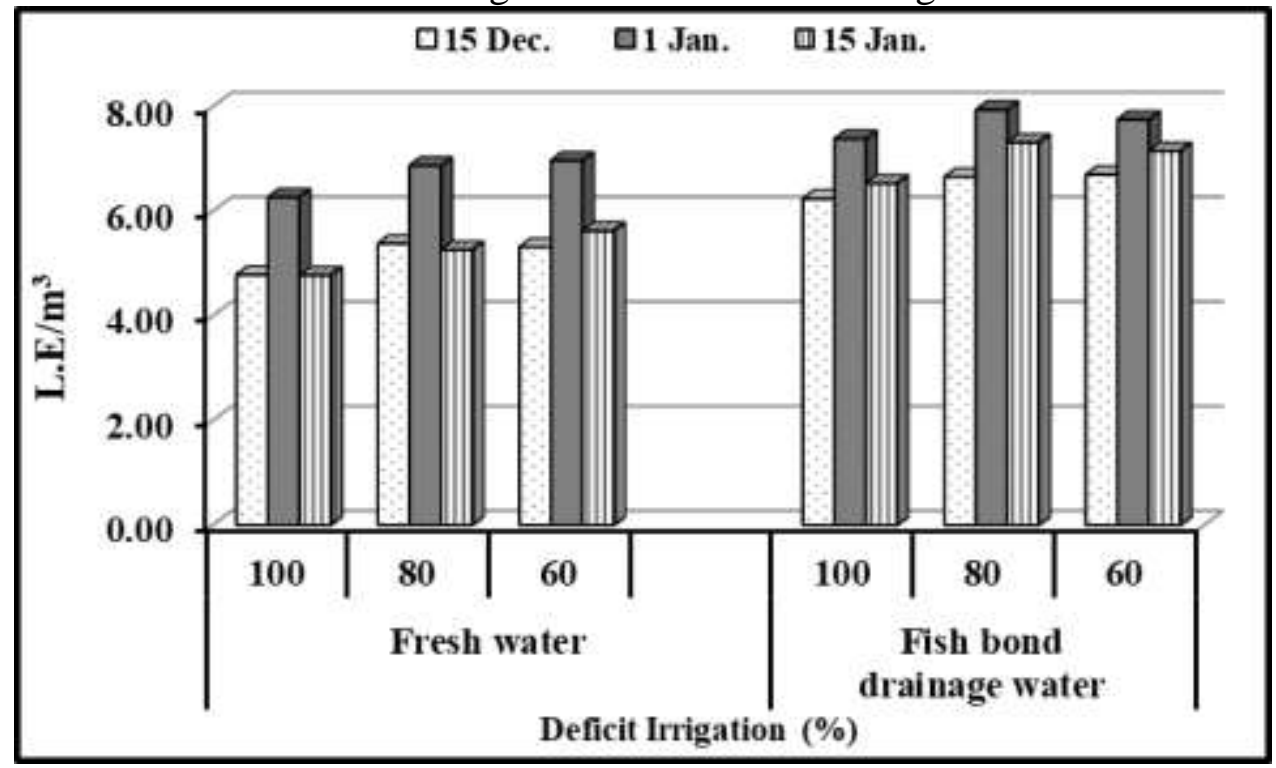

Fig. (9): Water productivity with deficit irrigation using fresh and brackish water

\section{Conclusions}

- Soil salinity decreased from $1.55 \mathrm{dS} / \mathrm{m}$ before planting to $1.33 \mathrm{dS} / \mathrm{m}$ after harvest whenbrackish water was used, while soil salinity after fresh water use was $1.23 \mathrm{dS} / \mathrm{m}$.

- Nitrogen values increased in soil from $177 \mathrm{~kg} / \mathrm{fed}$ before planting to $253 \mathrm{~kg} / \mathrm{fed}$ after planting when usingbrackish water compared to $180 \mathrm{~kg} / \mathrm{fed}$ after planting when using fresh water.

- Potassium oxide increased from $1321 \mathrm{~kg} / \mathrm{fed}$ before planting to $2254 \mathrm{~kg} / \mathrm{fed}$ after planting usingbrackish water, whereas in the case of freshwater the value of potassium oxide was $1350 \mathrm{~kg} / \mathrm{fed}$.

- The highest value of irrigation water quantity usingbrackish water was $2285 \mathrm{~m}^{3} / \mathrm{fed}$ at planting date of 15 December to add leaching needs. The highest irrigation water quantity using fresh water at planting date of 15 December was $2135 \mathrm{~m}^{3} / \mathrm{fed}$ at $100 \%$ of irrigation water, while the lowest value for the quantity of irrigation water using fresh water at $60 \%$ deficit was $1156 \mathrm{~m}^{3} / \mathrm{fed}$ at the planting date of January 15 , and the lowest quantity of irrigation water usingbrackish water was $1237 \mathrm{~m}^{3} / \mathrm{fed}$ in $60 \%$ deficit and at the planting date of 15 January due to the low number of irrigation times.

- The highest water use efficiency achieved at $80 \%$ irrigation water deficit, then at $60 \%$ and $100 \%$ respectively using both fresh andbrackish water. In the meantime, average water use efficiency was $1.28,1.46$ and $1.53 \mathrm{~kg} / \mathrm{m}^{3}$ when using $100 \%, 80 \%$ and $60 \%$, respectively, with a yield reduction of $10 \%$ and $38 \%$ for the use of water $80 \%$ and $60 \%$ respectively compared to $100 \%$. The average efficiency of water use when usingbrackish water was $1.48,1.65$ and $1.64 \mathrm{~kg} / \mathrm{m}^{3}$ when using $100 \%, 80 \%$ and $60 \%$ irrigation deficit 
respectively with a decrease in yield of $13 \%, 51 \%$ for the use of fresh water $80 \%$ and $60 \%$ respectively compared to $100 \%$.

- The highest net return was 16020, 14249 and 13457 LE/fed.usingbrackish water at 100\% of the irrigation water in planting dates of 1 January, 15 December and 15 January respectively, and the net return of about $6501 \mathrm{LE} / \mathrm{fed}$. using fresh water at $60 \%$ of irrigated water at planting date of January 15.

\section{Recommendations}

- The use of brackish water as an additional source of water for aquaculture production is highly recommended as it gives high production rates in addition to the reduction of fertility costs and enhancing the soil characteristics.

- When using the water for aquaculture, two filter stages (sand and screen) must be set to overcome clogging problems.

\section{REFERENCES}

Abdelraouf, R.E. and E.M.A. Hoballah (2014).Impact of irrigation systems, fertigation rates and using drainage water of fish farms in irrigation of potato under arid regions conditions. Int. J. Scientif. Res. Agric.t. Sci., 1(5): 67-79.

Andrew, W.L. (2008). Planting date and preplant weed management influence yield, water use, and weed seed production in herbicide-free forage barley. Weed Technol., 22: 486-492.

Israelsen, O.W. and V.E. Hansen (1962).Irrigation principles and practices $3^{\text {rd }}$ Edit., John Willey and Sons Inc., New York.

Macfadyen, G.; Nasr-allah, A.M.; Al-Kenawy, D.A.; Fathi, M.; Hebicha, H.; Diab Elshafei, A.M.; Hussein, S.M.; Ramadan Mohamed Abou Zied, R.M. and El-Naggar, G.O. (2011). Value-Chain Analysis of Egyptian Aquaculture,Project Report 54. DOI: 10.13140/2.1.1102.1769

Pene, C.B.G. and G.K. Edi (1996). Sugarcane yield response to deficit irrigation at two growth stages. In: Nuclear Techniques to Assess Irrigation Schedules for Field Crops. IAEA, TECDOC 888, pp. 115-129, Vienna.

Shabani, A.; Haghighi, A.; Sepaskhah, A.; Emam, Y. and Honar, T. (2010). Effect of water stress on grain yield, yield components and quality of winter rapeseed (Brasica napus L.). Iranian J. Crop Sci., 12: 409-421. 


\title{
Mohamed A.M.Moursy et al.
}

\author{
إمكانيه استخدام المياه الجوفية الثبه مالحه في أنظمة الزراعة المائية المتكاملة \\ محمد عنتر محمد مرسى 1 ، محمد حلمى راض1 ، احمد محسن على1 ، محمد الفتيان1، وليد البابلى2 2 \\ 1 \\ 2 - 2 - المركز القومى لبحوث المباهة المياه
}

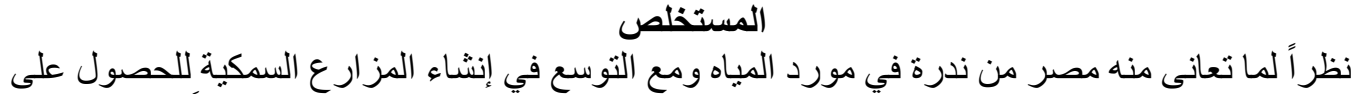

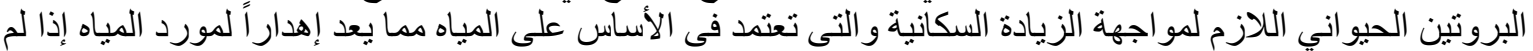

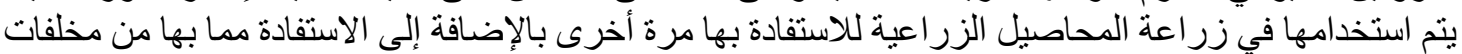

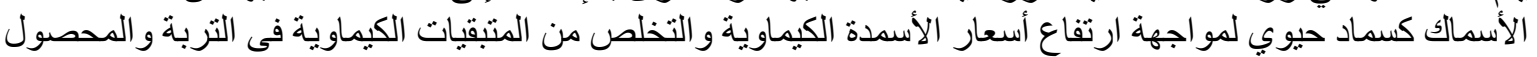

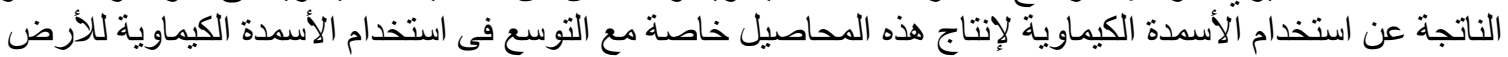

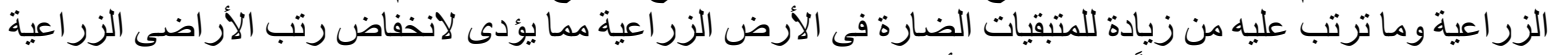

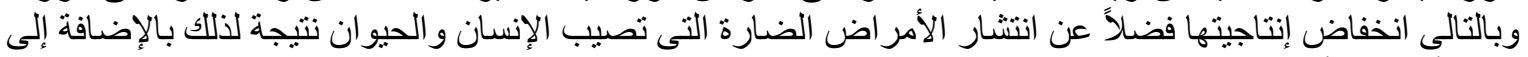

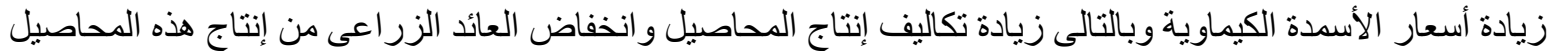

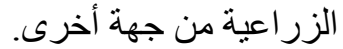

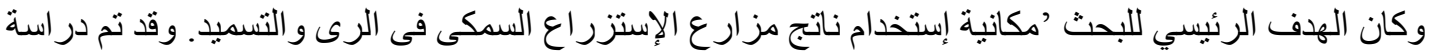

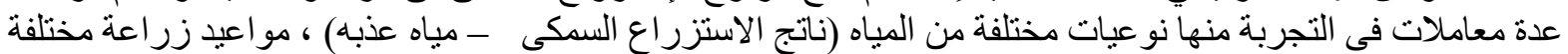

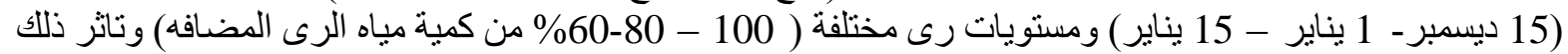

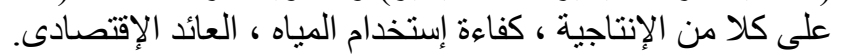

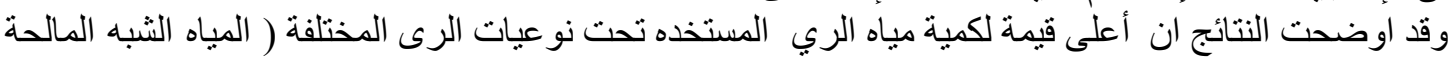

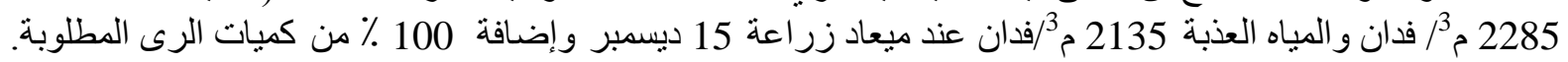

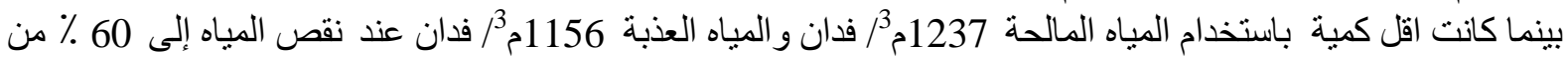

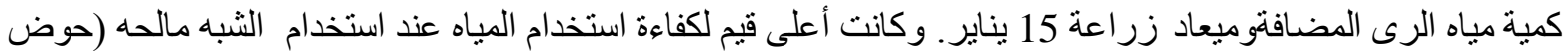

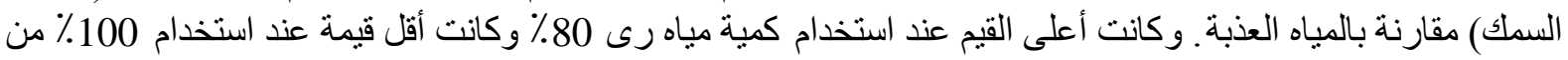

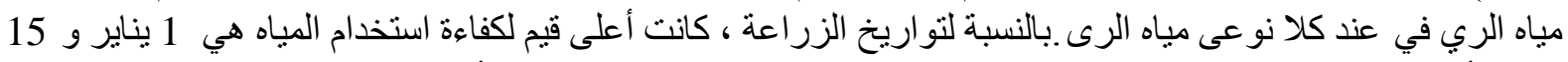

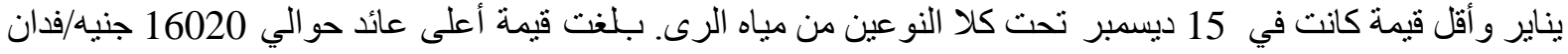

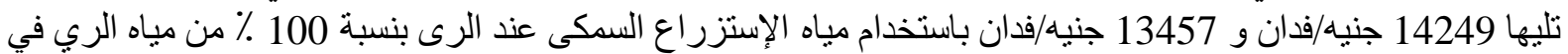

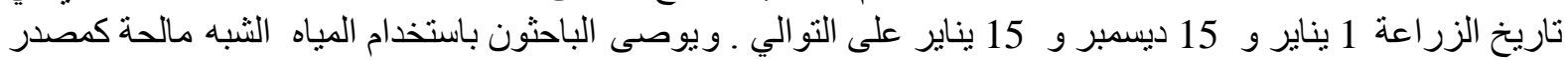

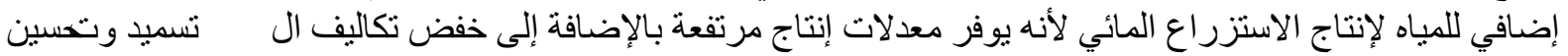

